\title{
Pengaruh Matriks Kombinasi Alginat:Gelatin (2\%:1\%) terhadap Karakteristik dan Aktivitas Antibakteri Mikrosfer Probiotik Lactobacillus acidophilus
}

Tutiek Purwanti*, Ria Puspita, Tristiana Erawati

Departemen Farmasetika, Fakultas Farmasi, Universitas Airlangga, Surabaya

*Corresponding author: tutiek_purwanti@yahoo.com

Submitted: 17 Mei 2019

Accepted: 8 Juli 2019

Published online: 31 Juli 2019

\begin{abstract}
Background: Microspheres is one of the drug delivery systems that can be use for oral or topical delivery. The effectiveness of the microspheres as the drug delivery system is influenced by the polymer matrix component. Objective: The purpose of this study was to determine the effect of combination matrix sodium alginate:gelatin (2\%:1\%) on the characteristics of probiotic microspheres such as size, entrapment efficiency, and this antibacterial activity. Methods: The microspheres were made by different matrix using combination matrix sodium alginate:gelatin (2\%:1\%) (F-I), probiotic microspheres with 3\% sodium alginate matrix (F-II) and probiotic microspheres with 3\% gelatin matrix (F-III). The probiotic microspheres are made by extrusion technique, and dried using an oven. Results: The average particle size of F-I, F-II, and F-III were $8.03 \mu \mathrm{m}, 9.69$ $\mu \mathrm{m}$, and $5.40 \mu \mathrm{m}$, respectively. The entrapment efficiency of F-I, F-II, and F-III were 77.48\%, $84.20 \%$ and 87.93\% respectively, while the antibacterial activity obtained inhibitory zone diameter of F-I, F-II, and F-III were $11.72 \pm 0.58 \mathrm{~mm}, 9.8 \pm 0.57 \mathrm{~mm}$, and $9.27 \pm 0.19 \mathrm{~mm}$, respectively. The results of statistical test using the ANOVA method and followed by the HSD test were known that there were significant differences between F-I, F-II, F-III. Conclusion: It can be concluded that the probiotic microsphere F-I has a smaller size than F-I and greater than F-III. Probiotic microsphere F-I have the lowest entrapment efficiency, but have the greatest antibacterial activity compared to probiotic microsphere F-II and F-III.
\end{abstract}

Keywords: microsphere, extrusion, sodium alginate, gelatin, probiotic Lactobacillus acidophilus

\begin{abstract}
Abstrak
Pendahuluan: Mikrosfer adalah salah satu sistem penghantaran obat yang dapat digunakan untuk menghantarkan obat pada pemakaian secara oral maupun topikal. Efektivitas mikrosfer sebagai sistem penghantar obat antara lain dipengaruhi oleh polimer penyusun matriknya. Tujuan: Tujuan dari penelitian ini untuk mengetahui pengaruh matrik natrium alginate $2 \%$ : gelatin $1 \%$ terhadap karakteristik mikrosfer probiotik yaitu ukuran, efisiensi penjebakan, dan aktivitas antibakteri yaitu diameter zona hambatnya. Metode: Dibuat mikrosfer probiotik dengan matriks berbeda yaitu kombinasi alginate:gelatin (2\%:1\%) (F-I), matriks alginat 3\% (F-II) dan matriks gelatin 3\% (F-III). Mikrosfer probiotik dibuat dengan teknik ekstrusi dan dikeringkan menggunakan oven. Hasil: Hasil pemeriksaan karakteristik menunjukkan bahwa rerata ukuran partikel F-I, F-II, dan F-III berturut-turut adalah 8,03 $\mu \mathrm{m}, 9,69 \mu \mathrm{m}$, dan 5,40 $\mu \mathrm{m}$. Efisiensi penjebakan F-I, F-II, dan F-III berturutturut adalah $77,48 \%, 84,20 \%$, dan 87,93\%. Sedangkan hasil uji aktivitas antibakteri, diperoleh diameter zona hambat F-I, F-II, dan F-III berturut-turut adalah 11,72 $\pm 0,58 \mathrm{~mm}, 9,8 \pm 0,57 \mathrm{~mm}$, dan 9,27, $\pm 0,19 \mathrm{~mm}$. Hasil uji statistik dengan metode ANOVA yang dilanjutkan uji HSD menunjukkan adanya perbedaan signifikan pada ukuran, efisiensi penjebakan maupun diameter zona hambat antara mikrosfer probiotik F-I, F-II, F-III. Kesimpulan: Disimpulkan bahwa mikrosfer probiotik F-I dengan matriks kombinasi alginat:gelatin (2\%:1\%) memiliki ukuran yang lebih kecil dari F-I (matriks alginat 3\%) dan lebih besar dari F-III (matriks gelatin 3\%).
\end{abstract}


Mikrosfer probiotik F-I memiliki harga efisiensi penjebakan paling rendah, tetapi memiliki aktivitas antibakteri paling besar dibandingkan dengan mikrosfer probiotik F-II dan F-III.

Kata kunci: mikrosfer, ekstrusi, natrium alginat, gelatin, probiotik Lactobacillus acidophilus

\section{PENDAHULUAN}

Probiotik (Lactobacillus acidophilus) dalam jumlah tertentu, yaitu $\geq 10^{7} \mathrm{cfu} / \mathrm{g}$ dapat memberikan efek terapi bagi kesehatan, khususnya saluran pencernaan (Halász, 2009; Flourou-Paneri dkk., 2013). Beberapa penelitian yang telah dilakukan juga menunjukkan bahwa Lactobacillus acidophilus dapat menghambat pertumbuhan bakteri penyebab infeksi kulit (Šušković dkk., 2010; Lew \& Liong, 2013). Hal ini disebabkan karena kandungan metabolit dari Lactobacillus acidophilus yaitu bakteriosin dapat bersifat sebagai antibakteri. Sehingga probiotik ini sangat potensial dikembangkan untuk penggunaan topikal untuk mengatasi acne, aging, rosaceae, dermatitis, inflamasi kulit dan infeksi bakteri (Lannitti \& Palmieri, 2010; Inostroza dkk., 2012).

Permasalahannya adalah probiotik ini tidak stabil terhadap faktor suhu, kelembaban, $\mathrm{pH}$, dan stres (Jood dkk., 2012). Sehingga untuk menjaga stabilitas dan memperpanjang efek farmakologi yang ditimbulkan, melalui pola pelepasan diperlambat diperlukan sistem penghantaran yang sesuai yaitu mikrosfer (Burgain dkk., 2011; Agnihotri dkk., 2012; Solanki dkk., 2013). Mikrosfer dibuat dengan cara mengenkapsulasi probiotik menggunakan matriks kombinasi natrium alginat-gelatin dengan penyambung silang larutan $\mathrm{CaCl}_{2}$. Dipilih metode ekstrusi, karena memiliki beberapa kelebihan yaitu sederhana, murah, mudah dilakukan, serta tidak menyebabkan kerusakan probiotik, karena tidak memerlukan suhu tinggi maupun pelarut organik (Manjanna dkk, 2010; Sahil dkk., 2011).

Karakteristik mikrosfer probiotik, dalam hal ini ukuran, efisiensi penjebakan dan aktivitas antibakteri dipengaruhi oleh jenis dan konsentrasi matriks, konsentrasi cross linker, $\mathrm{pH}$ saat pencampuran larutan matriks dan suspensi probiotik sebelum proses ekstrusi. Dalam proses mikroenkapsulasi dibutuhkan suatu matriks yang biasanya berupa polimer (Saijala dkk., 2011). Natrium alginat merupakan polimer alam yang banyak digunakan dalam proses mikroenkapsulasi karena sifatnya yang biokompatibel, biodegradabel, larut dalam air, tidak toksik dan relatif murah. Natrium alginat dapat membentuk gel dengan kation bervalensi dua antara lain ion $\mathrm{Ca}^{2+}$, sehingga pada penelitian ini digunakan larutan $\mathrm{CaCl}_{2}$ sebagai bahan penyambung silang. Selain keuntungan yang telah disebutkan, ternyata alginat memiliki kekurangan yaitu mikrosfer yang dihasilkan terlalu porus, sehingga kurang optimal dalam melindungi probiotik dari faktor lingkungan. Struktur yang porus tersebut juga akan mengakibatkan kemampuan menjebak probiotik rendah (Chávarri dkk., 2012). Oleh karena itu diperlukan polimer lain untuk meminimalkan kekurangan tersebut. Gelatin merupakan polimer yang bersifat biodegradabel, biokompatibel, stabil pada rentang $\mathrm{pH}$ yang luas, murah, memiliki daya pengembangan yang baik, dan bisa mengalami sambung silang seperti natrium alginat (GMIA, 2012; Elzoghby, 2013).

Karena sifat amfoternya, gelatin dapat dikombinasikan dengan polisakarida anionik seperti natrium alginat (Li dkk., 2009). Selain itu kombinasi natrium alginat dan gelatin sebagai matriks akan mengurangi porositas, karena matriks yang terbentuk lebih kompak, sehingga ukuran partikel lebih kecil dan kemampuan menjebak lebih besar (Li dkk., 2009).

Dalam penelitian ini, dibuat tiga macam mikrosfer probiotik yaitu F-I dengan matriks kombinasi natrium alginat:gelatin (2\%:1\%), F-II dengan matriks alginat $3 \%$ dan F-III dengan matriks gelatin 3\%. Mikrosfer probiotik ekstrusi dikeringkan menggunakan oven dengan temperatur kurang dari $40^{\circ} \mathrm{C}$. Selanjutnya dilakukan pemeriksaan ukuran partikel, efisiensi penjebakan dan aktivitas daya hambat terhadap pertumbuhan bakteri uji Staphylococcus auerus dengan mengukur diameter zona hambatnya.

\section{BAHAN DAN METODE Bahan}

Lactobacillus acidophilus dari Pusat Studi Pangan dan Gizi Universitas Gajah Mada, Staphylococcus aureus, gelatin tipe B (Pharmaceutical Grade), Natrium alginat (Pharmaceutical Grade), kalsium klorida (Food Grade), air suling steril, media de Man Ragosa Shorpe (MRS) Broth steril, Natrium Klorida (Pro Analisis), Phosphate Buffer Salin (PBS) steril, Agar AA (Food Grade) dan Media Nutrien Agar (NA) steril. 
Alat

Plate Stirer (Dragon Lab MS pro), $\mathrm{pH}$ meter SCHOTT glass mainz tipe CG 842, spektrofotometer FTIR (Jasco FT-IR/5300), alat Ekstrusi, Mikroskop Optik, incubator (Memmert INB 500), Colony counter
(Suntex 570), Vortex (Labinco L46), Autoklaf (Huxley HL340), Thermoshaker (Gerhardl Labshake), Ultra sentrifugator Hermle Z36HK timbangan analitik, Oven, Cawan Petri, Ôse, pipet mikro, jangka sorong.

Tabel 1. Formula mikrosfer probiotik

\begin{tabular}{lllll}
\hline Bahan & Fungsi & F-I & F-II & F-III \\
\hline *suspensi Probiotik: & Bahan Aktif & $10 \mathrm{~mL}$ & $10 \mathrm{~mL}$ & $10 \mathrm{~mL}$ \\
L. acidophilus & Matriks & $1,5 \mathrm{~g} \mathrm{(1 \% )}$ & - & $4,5 \mathrm{~g} \mathrm{(3 \% )}$ \\
Gelatin tipe B & Matriks & $3 \mathrm{~g} \mathrm{(2 \% )}$ & $4,5 \mathrm{~g} \mathrm{(3 \% )}$ & - \\
Natrium alginat & Pelarut & $140 \mathrm{~mL}$ & $140 \mathrm{~mL}$ & $140 \mathrm{~mL}$ \\
Aquadest & Cross linker & $300 \mathrm{~mL}$ & $300 \mathrm{~mL}$ & $300 \mathrm{~mL}$ \\
$\mathrm{CaCl}_{2} 1,5 \mathrm{M}$ & & & \\
\hline
\end{tabular}

* suspensi probiotik diambil saat jumlah mikroba minimal $10^{6}-10^{7} \mathrm{cfu} / \mathrm{mL}$

Keterangan:

F-I : Formula mikrosfer probiotik dengan matriks kombinasi natrium alginat:gelatin (2\%:1\%)

F-II : Formula mikrosfer probiotik dengan matriks natrium alginat 3\% (sebagai kontrol)

F-III : Formula mikrosfer probiotik dengan matriks gelatin 3\% (sebagai kontrol)

\section{Pembuatan mikrosfer probiotik}

Dibuat mikrosfer probiotik berbagai formula dengan matriks yang berbeda, sesuai komposisi yang tertera pada Tabel 1. Diukur probiotik $5 \mathrm{~mL}$ dari starter yang sudah memenuhi persyaratan. Disiapkan larutan natrium alginat dan gelatin dengan cara natrium alginat dan gelatin didispersikan ke dalam aquadest $140 \mathrm{~mL}$ sambil terus diaduk lalu disterilisasi pada suhu $121^{\circ} \mathrm{C}$ selama 20 menit. Selanjutnya masukkan suspensi probiotik ke dalam larutan natrium alginat-gelatin sambil diaduk sampai homogen, lakukan pemeriksaan jumlah koloni menggunakan metode Angka Lempeng Total (ALT) sebelum dilakukan proses ekstrusi. Siapkan larutan kalsium klorida 1,5 M $300 \mathrm{~mL}$ sebagai larutan penyambung silang. Disemprotkan campuran suspensi probiotik dan larutan polimer melalui noozle yang di bawahnya sudah ada media penampung yaitu larutan kalsium klorida 1,5 M. Ukuran diameter noozle $45 \mu \mathrm{m}$, jarak antara noozle dengan larutan kalsium klorida $8 \mathrm{~cm}$ dan tekanan kompresor 40 Psi. Dilakukan pengadukan selama 1 jam dengan kecepatan $1000 \mathrm{rpm}$. Mikrosfer yang terbentuk dipisahkan dari larutan $\mathrm{CaCl}_{2}$ dengan cara disentrifugasi $2500 \mathrm{rpm}$ selama 6 menit, lalu dicuci dengan air steril, sampai bebas $\mathrm{CaCl}_{2}$. Dilakukan penyaringan dan mikrosfer probiotik yang diperoleh dikeringkan menggunakan oven pada suhu $40^{\circ} \mathrm{C}$ selama 30 jam (Poshadri \& Kuna, 2010; Prasant dkk., 2011).

\section{Penentuan ukuran partikel}

Pengukuran ukuran partikel dilakukan menggunakan mikroskop optik yang dilengkapi dengan micrometer okular dan obyektif (Martin, 2002) dengan sampel 300 partikel mikrosfer.

\section{Uji efisiensi penjebakan}

Uji efisiensi penjebakan dilakukan menggunakan metode Angka Lempeng Total (ALT). Uji efisiensi penjebakan dilakukan untuk melihat adanya pengaruh proses pembuatan mikrosfer terhadap viabilitas bakteri. Ditimbang 0,5 gram mikrosfer probiotik, kemudian didispersikan ke dalam $50 \mathrm{~mL}$ larutan PBS steril pada $\mathrm{pH} 7,4$ dan di shaker selama 2 jam. Selanjutnya dilakukan pengenceran 10x, dan dilakukan plating pada media MRS agar. Kemudian diinkubasi pada suhu $37^{\circ} \mathrm{C}$ selama 48 jam. Perhitungan jumlah koloni bakteri probiotik diekpresikan dengan menggunakan satuan colony forming units (cfu)/gram (Mokarram dkk., 2009). Efisiensi penjebakan merupakan perbandingan antara jumlah koloni sesudah dibuat mikrosfer dengan jumlah koloni sebelum dibuat mikrosfer dikalikan $100 \%$.

\section{Uji aktivitas antibakteri \\ Preparasi media uji}

Bahan media nutrien agar (NA) sebanyak \pm 23 gram dilarutkan didalam \pm 1 liter air suling dan diaduk hingga homogen. Larutan dipanaskan dengan pemanasan perlahan, hingga mendidih selama satu sampai dua menit. Larutan yang sudah homogen dituang kedalam wadah dan disterilkan pada suhu $121^{\circ} \mathrm{C}$ selama 15 menit.

Bahan media nutrien broth (NB) sebanyak \pm 8 gram dilarutkan kedalam \pm 1 liter air suling dan diaduk 
hingga homogen. Larutan dipanaskan dengan pemanasan perlahan hingga mendidih selama satu atau dua menit. Setelah homogen larutan dituang kedalam wadah dan disterilkan pada suhu $121^{\circ} \mathrm{C}$ selama 15 menit.

\section{Penyiapan sampel}

Ditimbang 200 miligram mikrosfer probiotik, dicampur dengan $10 \mathrm{~mL}$ larutan PBS 7,4 steril dan di shaker selama 2 jam.

\section{Penyiapan inokulum bakteri}

Sebanyak 1 kawat Öse biakan murni S. aureus dari stok biakan dimasukkan pada media NB. Kemudian tabung disimpan dalam inkubator suhu $37^{\circ} \mathrm{C}$ selama 24 jam. Sebanyak $5 \mathrm{~mL}$ larutan garam fisiologis (salin) ditambahkan ke dalam tabung, dikocok sampai seluruh biakan terlepas sehingga didapatkan $1,4 \times 10^{8} \mathrm{cfu}$. Biakan setara dengan absorban 0,885 diukur dengan spektrofotometer pada panjang gelombang $580 \mathrm{~nm}$ sampai diperoleh transmitan $25 \%$ (Johnson \& Levin, 2013).

\section{Uji aktivitas daya hambat terhadap Staphylococcus aureus}

Disiapkan 2 buah tabung reaksi yang masingmasing berisi media NA steril sebanyak $8 \mathrm{~mL}$ (seed layer) dan $10 \mathrm{~mL}$ (base layer). Media base layer dituangkan kedalam cawan petri steril, dibiarkan memadat. Masukkkan $3 \mu \mathrm{m}$ inokulum S. aureus kedalam tabung seed layer pada suhu $40-45^{\circ} \mathrm{C}$, kemudian di vortex. Selanjutnya dituang secara merata pada permukaan base layer dalam cawan petri dan biarkan memadat. Dibuat lubang atau sumuran pada agar dengan pipa pencetak sesuai dengan ketentuan. Isi masing-masing lubang tersebut dengan $50 \mu \mathrm{L}$ yaitu 1 (kontrol positif), 1 (kontrol negatif), 1 (suspensi probiotik), 3 (sampel F-I), 3 (sampel F-II), dan 3 (sampel F-III), kemudian cawan petri dibungkus kertas dan diinkubasi pada suhu $37^{\circ} \mathrm{C}$ selama 24 jam. Diameter zona terang yang terbentuk diamati dan diukur menggunakan jangka sorong (milimeter). Sebagai kontrol positif digunakan antibiotik gentamisin sulfat, sedangkan kontrol negatif adalah semua bahan dalam formula selain suspensi probiotik. Pengujian dilakukan tiga kali replikasi untuk masing-masing sampel uji.

\section{Analisa data}

Pengolahan data karakteristik yaitu ukuran, efisiensi penjebakan dan aktifitas anti bakteri $L$. acidophilus dilakukan secara statistik dengan metode analisis varian one way ANOVA, yang dilanjutkan dengan uji Honesty Significant Difference (HSD) Tukey dengan derajat kepercayaan 0,95 $(\alpha=0,05)$.

\section{HASIL DAN PEMBAHASAN Morfologi mikrosfer probiotik}

Dari hasil pengamatan mikrosfer probiotik yang dilihat di bawah mikroskop optik perbesaran 400x terlihat mikrosfer yang sferis. Hal ini disebabkan karena pada proses pembuatan larutan polimerprobiotik disemprotkan melewati lubang/pori dengan ukuran tertentu, sehingga membentuk droplet cair yang sferis dan ketika mengalami pemadatan akibat proses sambung silang menghasilkan mikrosfer yang sferis juga (Joshi dkk., 2012).

\section{Distribusi ukuran mikrosfer probiotik}

Hasil pengukuran mikrosfer probiotik menggunakan mikroskop dengan skala okuler 10 dan skala objektif 40. Digunakan 300 partikel pada setiap kali pengukuran. Hasil penentuan ukuran partikel diperoleh rerata ukuran mikrosfer probiotik seperti yang tercantum pada Tabel 2 berikut.

Tabel 2. Rerata ukuran mikrosfer probiotik

\begin{tabular}{lc}
\hline \multicolumn{1}{c}{ Mikrosfer Probiotik } & Rata-rata Ukuran $(\mu \mathrm{m})$ \\
\hline F-I (Alginat:Gelatin (2\%:1\%)) & 8,03 \\
F-II (Alginat 3\%) & 9,69 \\
F-III (Gelatin 3\%) & 5,40 \\
\hline
\end{tabular}

Rerata ukuran mikrosfer probiotik F-I, F-II, dan FIII berturut-turut adalah 8,03 $\mu \mathrm{m}, \quad 9,69 \mu \mathrm{m}$, dan $5,40 \mu \mathrm{m}$. Ukuran partikel terkecil pada F-III yaitu mikrosfer probiotik dengan matrik gelatin 3\% dan ukuran terbesar adalah pada F-II yaitu mikrosfer probiotik dengan matrik natrium alginat $3 \%$. Sedangkan F-I yaitu mikrosfer probiotik dengan matriks kombinasi natrium alginat:gelatin (2\%:1\%) memiliki ukuran lebih besar dari F-III, lebih kecil dari
F-II. Natrium alginat tersusun atas asam guluronat (blok G) dan manuronat (blok M). Pada proses sambung silang terjadi interaksi antara ion $\mathrm{Ca}^{2+}$ dengan gugus karboksil pada asam guluronat yang saling berdekatan saja, sedangkan gugus karboksil pada asam manuronat tetap berjajar horizontal dalam keadaan bebas, sehingga menyebabkan ukuran partikel natrium alginat lebih besar dibandingkan dan struktur yang terbentuk porus. Sedangkan pada mikrosfer probiotik 
F-I dengan matriks kombinasi natrium alginat-gelatin terbentuk struktur yang lebih kompak dengan porositas yang rendah. Sehingga mikrosfer yang terbentuk memiliki ukuran lebih kecil.
Berdasarkan distribusinya, ukuran dari mikrosfer probiotik F-I, F-II, dan F-III berkisar antara 3 sampai 15 mikron, sehingga masih memenuhi persyaratan ukuran untuk mikrosfer dengan tujuan penggunaan topikal.

Tabel 3. Hasil perhitungan log ALT Lactobacillus acidophilus

\begin{tabular}{ccccc}
\hline \multirow{2}{*}{ Formula } & \multicolumn{2}{c}{ ALT $(\mathrm{cfu} / \mathrm{mL})$} & \multicolumn{2}{c}{ log ALT (cfu/mL) } \\
\cline { 2 - 5 } & $\begin{array}{c}\text { Sebelum dibuat } \\
\text { mikrosfer }\end{array}$ & $\begin{array}{c}\text { Setelah dibuat } \\
\text { mikrosfer }\end{array}$ & $\begin{array}{c}\text { Sebelum dibuat } \\
\text { mikrosfer }\end{array}$ & $\begin{array}{c}\text { Setelah dibuat } \\
\text { mikrosfer }\end{array}$ \\
\hline F-I & $9,37 \times 10^{7} \pm 3,51 \times 10^{6}$ & $1,15 \times 10^{6} \pm 7,4 \times 10^{4}$ & $7,97 \pm 0,01$ & $6,06 \pm 0,02$ \\
\hline F-II & $1,58 \times 10^{7} \pm 1,07 \times 10^{6}$ & $1,08 \times 10^{6} \pm 7,35 \times 10^{4}$ & $7,20 \pm 0,03$ & $6,03 \pm 0,03$ \\
\hline F-III & $7,60 \times 10^{6} \pm 7,94 \times 10^{5}$ & $1,02 \times 10^{6} \pm 1,39 \times 10^{4}$ & $6,88, \pm 0,04$ & $6,01 \pm 0,00$ \\
\hline
\end{tabular}

Keterangan: Data merupakan rata-rata dari replikasi $3 \mathrm{x} \pm \mathrm{SD}$

Dari Tabel 3 diketahui bahwa terjadi penurunan jumlah koloni pada masing-masing mikrosfer probiotik, sebagai akibat proses ekstrusi. Nilai ALT terkecil terjadi pada F-III, namun jumlah koloni ketiga mikrosfer probiotik masih memenuhi persyaratan viabilitas yang dibutuhkan yaitu $10^{6}-10^{7} \mathrm{cfu} / \mathrm{mL}$ (Flourou-Paneri dkk., 2013).

Tabel 4. Efisiensi penjebakan mikrosfer probiotik

\begin{tabular}{cc}
\hline $\begin{array}{c}\text { Mikrosfer } \\
\text { Probiotik }\end{array}$ & Efisiensi Penjebakan $(\%)$ \\
\hline F I & $77,48 \pm 0,17$ \\
\hline F II & $84,20 \pm 0,16$ \\
\hline F III & $87,93 \pm 0,43$ \\
\hline
\end{tabular}

Keterangan: Data merupakan rata-rata dari replikasi $3 \mathrm{x} \pm \mathrm{SD}$

Dari Tabel 4 dapat diketahui bahwa ada pengaruh proses pembuatan mikrosfer terhadap viabilitas Lactobacillus acidophilus dalam mikrosfer yaitu terjadinya penurunan viabilitas yang ditunjukkan adanya penurunan jumlah koloni bakteri.

Efisiensi penjebakan diperhitungkan sebagai jumlah koloni bakteri sesudah proses (terjebak dalam mikrosfer) dibagi dengan jumlah koloni sebelum dilakukan proses ekstrusi kemudian dikalikan $100 \%$. Hasil perhitungan koloni dengan metode ALT diperoleh nilai ALT mikrosfer probiotik F-I, F-II dan F-III sebelum ekstrusi berturut-turut adalah 9,37 x $10^{7}$ $\pm 3,51 \times 10^{6} \mathrm{cfu} / \mathrm{g}, 1,58 \times 10^{7} \pm 1,07 \times 10^{6} \mathrm{cfu} / \mathrm{mL}$, dan $7,60 \times 10^{6} \pm 7,94 \times 105 \mathrm{cfu} / \mathrm{mL}$. Nilai ALT dari ketiga formula memenuhi syarat jumlah probiotik sebagai antibakteri yaitu $10^{6}-10^{7} \mathrm{cfu} / \mathrm{mL}$ (Flourou-Paneri dkk., 2013). Nilai ALT F-I, F-II dan F-III setelah proses ekstrusi berturut-turut adalah $1,15 \times 10^{6} \pm 7,4 \mathrm{x}$ $10^{4} \mathrm{cfu} / \mathrm{mL}, 1,08 \times 10^{6} \pm 7,35 \times 10^{4} \mathrm{cfu} / \mathrm{mL}$, dan $1,02 \times$ $10^{6} \pm 1,39 \times 10^{4} \mathrm{cfu} / \mathrm{mL}$. Dari data ini dapat disimpulkan bahwa ada pengaruh pembuatan mikrosfer terhadap efisiensi penjebakan bakteri yaitu mengalami penurunan jumlah bakteri yang hidup. Hasil penentuan efisiensi penjebakan dari ketiga mikrosfer berturut turut formula I, II, dan III adalah 77,48\%, 84,20\%, dan $87,93 \%$. Hasil analisa statistik dengan One Way Anova dan post hoc HSD, diketahui bahwa terdapat perbedaan signifikan pada ketiga mikrosfer probiotik. Efisiensi penjebakan terendah terjadi pada mikrosfer probiotik F-I dan tertinggi pada mikrosfer probiotik F-III. Namun ketiga mikrosfer probiotik masih memenuhi ketentuan viabilitas yang dipersyaratkan.

\section{Uji aktivitas antibakteri mikrosfer probiotik}

Uji aktivitas antibakteri dilakukan menggunakan bakteri uji $S$. aureus dengan cara mengukur diameter zona hambatnya. S. aureus adalah bakteri patogen yang dapat menyebabkan infeksi pada kulit. Hasil pengukuran diameter zona hambat ketiga formula mikrosfer probiotik dapat dilihat pada Tabel 5 . Diameter zona hambat mikrosfer probiotik F-I, F-II, dan F-III berturut turut adalah 11,72 $\pm 0,58 \mathrm{~mm}, 9,8 \pm$ $0,57 \mathrm{~mm}$, dan 9,27 $\pm 0,19 \mathrm{~mm}$. Setelah dilakukan analisa statistik One Way Anova dilanjutkan post hoc HSD, terdapat perbedaan signifikan aktivitas antibakteri pada ketiga mikrosfer probiotik tersebut. Mikrosfer probiotik dengan matriks kombinasi alginat dan gelatin memberikan aktivitas yang lebih besar dibanding formula dengan polimer tunggal, baik natrium alginat $3 \%$ maupun gelatin 3\%. Diameter zona hambat tertinggi dihasilkan oleh mikrosfer probiotik FI yaitu sebesar $11,72 \pm 0,58 \mathrm{~mm}$.

Tabel 5. Diameter zona hambat mikrosfe probiotik

\begin{tabular}{lc}
\hline Mikrosfer & Zona Hambat $(\mathrm{mm})$ \\
\hline Mikrosfer F-I & $11,72 \pm 0,58$ \\
\hline Mikrosfer F-II & $9,8 \pm 0,57$ \\
\hline Mikrosfer F-III & $9,27 \pm 0,19$ \\
\hline Kontrol Positif & $13,22 \pm 0,01$ \\
\hline
\end{tabular}

Keterangan:

Data merupakan rata-rata dari replikasi $3 \mathrm{x} \pm \mathrm{SD}$

Kontrol positif $=$ Gentamisin sulfat 
Berdasarkan hasil Log ALT (setelah ekstrusi dan oven) dan aktivitas menunjukan bahwa hasil Log ALT mikrosfer probiotik F-I > F-II > F-III, dan aktivitas antibakteri F-I > F-II > F- III. Terlihat bahwa harga log ALT linier dengan aktivitas antibakteri, semakin besar harga $\log$ ALT, maka semakin tinggi pula aktivitas antibakterinya.

Efisiensi penjebakan F-III > F-II > F- I, namun uji aktivitas F-I > F- II > F-III. Hal ini menunjukan bahwa mikrosfer probiotik F-I dengan matriks kombinasi natrium alginat-gelatin menghasilkan efisiensi penjebakan terendah namun memberikan aktivitas antibakteri paling tinggi dibanding formula lain. Hal ini dapat dijelaskan dengan data transmitan. Dimana \% transmitan F-I, F-II dan F-III berturut turut adalah $81,60 \%, 85,60 \%$, dan $89,50 \%$. Sedangkan hasil efisiensi penjebakan pada formula I, II dan III adalah $77,48 \%, 84,20 \%$, dan $87,93 \%$. Semakin rendah transmitan, berarti semakin kecil intensitas cahaya yang diteruskan. Hal dikarenakan semakin banyak jumlah sel bakteri. Oleh karena itu, pada F-I aktivitas antibakterinya paling tinggi, meskipun efisiensi penjebakannya paling rendah. Hal ini disebabkan karena transmitan F-I paling rendah.

Setelah dilakukan kesetaraan konsentrasi terhadap kontrol positif gentamisin sulfat dapat disimpulkan bahwa mikrosfer probiotik F-I, F-II, dan F-III memiliki nilai diatas harga MIC gentamisin sulfat. Minimum Inhibitory Concentration (MIC) adalah konsentrasi terendah suatu antibakteri yang dapat menghambat kehidupan mikroorganisme lain (Kumar \& Kar, 2014). Kesetaraan konsentrasi mikrosfer probiotik F-I, F-II, dan F-III dengan gentamisin sulfat secara berturut turut adalah 4,45 ppm, 1,19 ppm, dan 0,30 ppm, sedangkan MIC gentamisin sulfat terhadap bakteri Staphylococcus aureus adalah 0,71 ppm (Johnson \& Levin, 2013). Dapat disimpulkan bahwa mikrosfer probiotik F-I dan F-II mempunyai efektivitas sebagai antibakteri.

\section{KESIMPULAN}

Mikrosfer probiotik dengan matriks kombinasi natrium alginat-gelatin (2\%:1\%) memiliki efisiensi penjebakan Lactobacilus acidophilus paling kecil, dan aktivitas antibakteri terhadap Staphylococcus aureus paling besar dibandingkan dengan mikrosfer probiotik dengan matriks natrium alginat 3\% dan matriks gelatin 3\%. Sedangkan ukuran partikelnya lebih kecil dari mikrosfer probiotik dengan matriks natrium alginat $3 \%$, tetapi lebih besar dari mikrosfer probiotik dengan matriks gelatin $3 \%$.

\section{DAFTAR PUSTAKA}

Agnihotri, N., Mishra, R., Goda, C. \& Arora, M. (2012). Microencapsulation - A Novel Approach in Drug Delivery: A Review. Indo Global Journal of Pharmaceutical Sciences; 2; 1-20.

Burgain, J., Gaiani, C., M., Linder \& Scher, J. (2011). Encapsulation of Probiotic Living Cells: From Laboratory Scale to Industrial Applications. Journal of Food Engineering; 104; 467-483.

Chávarri, M, Marañó, I. \& Villarán, C. (2012). Encapsulation Technology to Protect Probiotic Bacteria. London: IntechOpen.

Elzoghby, A. E. (2013). Gelatin-based Nanoparticles as Drug and Gene Delivery Systems: Reviewing three Decades of Research. Journal of Controlled Release; 172; 1075-1091.

Flourou-Paneri, P., Christaki, E. \& Bonos, E. (2013). Lactic Acid Bacteria as Source of Functional Ingredients: Lactic Acid Bacteria $-\mathrm{R} \& \mathrm{D}$ for Food. London: IntechOpen.

GMIA. (2012). Gelatin Handbook. Massacusetts: Atlantic Gelatin/Kraft Foods Global Inc.

Halász, A. (2009). Food Quality and Standards Vol III: Lactic Acid Bacteria. Oxford: EOLSS Publication.

Inostroza, E. C., Yanez, B., Riquelme, G. \& Storh, K. (2012). Formulation Based on the Synthesis of Microspheres Made from Cross Linked Natural Gelatin, Used as a Carrier for Strains of Probiotic Lactobaciillus spp. for Treating Skin Wounds and/or Lesions. Paris: European Patient Application.

Johnson, P. J. T. \& Levin, B. R. (2013). Pharmacodynamics, Population Dynamics, and the Evolution of Persistence in Staphylococcus aureus. PLOS Genetics; 9; 1-13.

Jood, S., Khetarpaul, N. \& Goyal, R. (2012). Effect of Germination and Probiotic Fermentation on $\mathrm{pH}$, Titratable Acidity, Dietary Fibre, $\beta$-glucan and Vitamin Content of Sorghum Based Food Mixtures. International Journal of Food Sciences and Nutrition; 2; 1-4.

Joshi, S., Patel, P., Lin, S. \& Madan, P. L. (2012). Development of Cross Linked Alginate Spheres by Ionotropic Gelation Technique for Controlled Release of Naproxen Orally. Asian Journal of Pharmaceutical Science; 7; 134-142.

Kumar, R. \& Kar, A. (2014). Microencapsulation of Nutraceuticals Using Spray Freeze Drying Method: A Brief Review. Indo Global Journal of Pharmaceutical Sciences; 4; 47-51. 
Lannitti, T. \& Palmieri, B. (2010). Therapeutical Use of Probiotic Formulations in Clinical Practice. Clinical Nutrition; 29; 701-725.

Lew, L. C. \& Liong, M. T. (2013). Bioactives from Probiotics for Dermal Health: Functions and Benefits. Journal of Applied Microbiology; 114; 1241-1253.

Li, X. Y., Chen, X. G., Cha, D. S., Park, H. J. \& Liu, C. S. (2009). Microencapsulation of a Probiotic Bacteria with Alginate-Gelatin and Its Properties. Journal of Microen-capsulation; 26; 315-324.

Manjanna, K. M., Pramodkumar, T. M. \& Shivakumar, B. (2010). Calcium Alginate Cross-linked Polymeric Microbeads for Oral Sustained Drug Delivery in Arthritis. Drug Discoveries and Therapeutics; 4; 109-122.

Martin, M. (2002). Surfactans and Polymers in Drug Delivery. New York: Marcel Dekker, Inc.

Mokarram, R. R., Mortazavi, S. A., Habibi, N. M. B. \& Shahidi, F. (2009). The Influence of Multi Stage Alginat Coating on Survivability of Potential Probiotic Bacteria in Simulated Gastric and Intestinal Juice. Food Research International; 42; 1040-1045.

Poshadri, A. \& Kuna, A. (2010). Microen-capsulation Technology: A Review. The Journal of Research Angrau; 38; 86-102.
Prasant, V. V., Moy, A. C., Mathew, S. T. \& Manthapan, R. (2011). Microspheres - An Overview. International Journal of Research in Pharmaceutical and Biomedical Sciences; 2; 332-338.

Sahil, K., Akanksha, M., Premjeet, S., Bilandi, A. \& Kapoor, B. (2011). Microsphere: A Review. International Journal Of Research In Pharmacy And Chemistry; 1; 1184-1198.

Saijala, A., Krishna, P., Amareshwar \& Chakravarty, P. (2011). Different Techniques Used for the Preparation of Nanoparticles using Natural Polymers and Their Application. International Journal of Pharmacy and Pharmaceutical Science; 3; 45-50.

Solanki, H. K., Pawar, D. D., Dushyant, A. S., Prajapati, V. D., Jani, G. K., Mulla, A. M., Thakar, P. M. (2013). Development of Microencapsulation Delivery System for LongTerm Preservation of Probiotis as Biotherapeutics Agent. BioMed Research International; 2013; 1-21.

Šušković, J., Kos, B., Beganović, J., Leboš Pavunc, A., Habjanič, K. \& Matošić, S. (2010). Antimicrobial Activity - the Most Important Property of Probiotic and Starter Lactic Acid Bacteria. Food Technology and Biotechnology; 48; 296-307. 